\title{
Reprosecution of patients found unfit to plead: a report of anomalies in procedure in Scotland
}

\author{
Derek Chiswick, Consultant Forensic Psychiatrist, Royal Edinburgh Hospital, \\ Morningside Park, Edinburgh EH10 5HF (correspondence); AlEXANDER P. W. \\ ShUBSACHS, Consultant Forensic Psychiatrist, Rampton Hospital, Retford, \\ Nottinghamshire DN22 0PD (formerly Lecturer in Forensic Psychiatry, University of \\ Edinburgh); and STEven Novosel, Consultant Forensic Psychiatrist, State Hospital, \\ Carstairs Junction, Lanarkshire ML11 8RP
}

A legal finding of unfitness to plead results in automatic committal of the accused to a mental hospital. In Scotland, if criminal proceedings are under solemn jurisdiction, there is a mandatory order restricting discharge without limit of time and the hospital must be a state hospital unless for special reasons an alternative hospital is appropriate (Section 174 of the Criminal Procedure [Scotland] Act 1975). The mental condition of a person found unfit to plead may subsequently improve such that he may become fit to be tried in the normal way. In England and Wales the Home Secretary has power, under Section 5(4) of the Criminal Procedure (Insanity) Act 1964, to remit to prison for trial a person found unfit to plead who subsequently recovers. On arrival of such a person in prison the hospital and restriction orders cease to have effect. The Criminal Procedure (Insanity) Act 1964 does not apply to Scotland; authority to reprosecute unfit defendants in sheriff courts and the High Court rests exclusively with procurators fiscal and the Crown Office respectively. The status of the original hospital and restriction orders in reprosecuted cases is unclear.

Two recent cases of patients found insane in bar of trial (unfit to plead) in Scotland, who were subsequently reprosecuted, demonstrate uncertainty in the current arrangements. In each case the restriction order remained in force after retrial, even though one patient was subsequently acquitted and the second was prosecuted under summary jurisdiction and made the subject of a hospital order with no restrictions on discharge.

\section{Case 1}

In December 1986 at the High Court in Edinburgh a 49-year-old woman was found insane in bar of trial on a charge of murder of her 4-month-old grand-daughter and was committed to the State Hospital in terms of section 174 of the Criminal Procedure (Scotland) Act 1975. She was a housewife who had become mentally unwell in the months before the alleged offence though she had not previously been referred for treatment. After four month's treatment her responsible medical officer recommended that she was now sane and fit to plead. She returned to court in September 1987 and pled not guilty to a charge of murder. On the third day of her trial the judge ordered dismissal of the case against her on the grounds of insufficient evidence. She was allowed to walk free from the court. However doubts continued about the applicability of the original order under section 174, discharge from which must be authorised by the Secretary of State for Scotland. Efforts were made to trace the lady who was by now living in London. One month after her acquittal the Secretary of State authorised her absolute discharge.

\section{Case 2}

In January 1985 at Dunoon Sheriff Court a 28-year-old man was found insane in bar of trial on a charge of assault to severe injury upon his father. He was committed to the State Hospital in terms of section 174 of the Criminal Procedure (Scotland) Act 1975. He was an unemployed oilrig worker who had four previous admissions to mental hospitals with a diagnosis of schizophrenia. His mental condition improved and after a few months his responsible medical officer informed the procurator fiscal that the patient was now sane and fit to plead. A decision was made to prosecute under summary procedure and he appeared in court in July 1985 when he pled guilty to assault. The sheriff made an order under section 376 (1) and (7) of the 1975 Act for admission to the State Hospital but he made no order restricting discharge as he might have done under section 379 of the same Act. The continued applicability of the original section 174 order was a matter of some doubt. It was concluded that since the restriction order had not been discharged by the Secretary of State for Scotland, it remained a valid instrument. Thus the patient continued to be subject to its requirements and consequently neither his responsible medical officer nor the Mental Welfare Commission for Scotland had authority to discharge him from hospital. In March 1987 the Secretary of State authorised the patient's transfer to an ordinary mental hospital and subsequently his conditional discharge in October 1987. He remained subject to the requirements in his licence of conditional discharge until September 1989 when he was absolutely discharged by the Secretary of State. 


\section{Comment}

The result of fresh criminal proceedings against a defendant might reasonably be expected to supersede any previous decision made by the court in that case. We have described two cases which clearly show this not to be so for patients in Scotland who are reprosecuted after being found unfit to plead. For the female patient the consequences were not significant; she was probably unaware that she was still 'detained' under a restriction order while free in the community. The outcome for the male patient was much more important. His situation remained exactly as it would have been had he not been reprosecuted. Fresh court proceedings were of no actual benefit to him or to the public which bore the cost of those proceedings; they were a paper exercise of no consequence.

Reprosecution of patients who have been found unfit to plead rarely takes place, and unsatisfactory features of procedure in Scotland have been extensively reviewed by Normand (1984). However the anomaly we have described was not a feature in any of the three cases cited by Normand and is not mentioned by him. The patients he described were all discharged from hospital, then immediately re-arrested and taken into police custody (so-called 'gate arrest'). In Scotland this procedure achieves the same effect as that which follows section 5(4) of the Criminal Procedure (Insanity) Act 1964 in England and Wales: the accused faces trial in exactly the same legal position as any other remanded prisoner.

However section 5(4) of the 1964 Act, and the cumbersome equivalent exercise in Scotland, may not be appropriate for an unfit to plead patient who recovers sufficiently to be fit to plead, but who may still be mentally disordered and may require treatment in hospital. Is there any benefit in such patients returning to court for reprosecution? We think there certainly is. Fresh criminal proceedings may result in acquittal (as in case 1 above); in such cases any further psychiatric treatment could take place either with the patient's agreement or, if necessary, under the civil provisions of mental health legislation. In cases where conviction follows, then the court has available to it the full range of psychiatric disposals including a psychiatric probation order, an interim hospital order and a hospital order. Reprosecution enables the most appropriate disposal to be selected, whereas unfitness to plead carries a fixed disposal which may be clinically unwarranted (Emmins, 1986; Chiswick, 1990). Even in reprosecuted cases where a hospital order is made, the imposition of an order restricting discharge (which has crucial implications for the patient and the treating doctor) is optional, and it can only be made after the court has heard oral evidence on the matter from a psychiatrist. In case 2 (above) a hospital order without restrictions was precisely the disposal selected after reprosecution but it proved to be a futile recommendation.

Proposals for changes in the law relating to unfitness to plead were made by the (Butler) Committee on Mentally Abnormal Offenders (Home Office and Department of Health and Social Security, 1975) for England and Wales, and by the (Thomson) Committee on Criminal Procedure in Scotland (Scottish Home and Health Department and Crown Office, 1975). Butler and Thomson recommended that a finding of unfitness should be followed by a determination of the facts and that the court should have available a range of disposal options. Both committees considered the question of reprosecution but neither mentioned the anomaly to which we have referred. It is unlikely that either committee would have countenanced a situation whereby the finding of the original prosecution was not vitiated after the case had been dealt with a second time by a court.

Reprosecution is of particular importance in Scotland where a proportionately larger number of defendants are found unfit to plead than in England and Wales (Chiswick, 1978). Normand drew attention to the very small number of cases that were reprosecuted and noted the then absence of any system for "routine follow up by the prosecution of insanity in bar of trial cases". According to the Thomson Report, the Crown "does not exercise this right [to reprosecute defendants found unfit to plead who recover] to any great extent, confining any such action to cases where the accused is liberated after a very short spell in hospital". This assertion did not apply in the two patients described above who were both reprosecuted while detained in hospital.

Prosecution authorities in Scotland have now adopted a policy for considering the reprosecution of unfit to plead patients detained in hospital (Crown Agent, personal communication). This requires procurators fiscal to seek medical information concerning patients who have been admitted to hospital after a finding of insanity in bar of trial. Information from the treating psychiatrist should include an opinion on the patient's fitness to plead and on the need, or otherwise, for continued treatment in hospital. In summary cases reprosecution will not normally take place beyond six months from the making of the hospital order. For defendants dealt with under solemn procedure in a sheriff court, reprosecution will not normally take place after two years from the original hospital order. In cases heard in the High Court, and in other exceptional cases, decisions on reprosecution are made by Crown Counsel.

This policy, although welcome, does not address the issue raised in the two cases we have described above. Here, reform of the law is necessary to ensure that the consequence of reprosecution has real meaning. The disposal made by the court at the initial 
prosecution should cease to have effect when fresh proceedings are taken, e.g. On arrival of the accused in court. The recently adopted policy on reprosecution, together with legislative change, would ensure that the effect of a finding of unfitness to plead would not necessarily be permanent. Psychiatric disorders run a fluctuating course and the capacity of a person to stand trial may similarly alter over time. Court procedure and criminal legislation should reflect these clinical facts.

\section{Acknowledgement}

The co-operation of the Crown Office in the preparation of this paper is gratefully acknowledged but the opinions expressed are entirely those of the authors.

\section{References}

CHiswick, D. (1978) Insanity in bar of trial: a state hospital study. British Journal of Psychiatry, 132, 598-601.

- (1990) Criminal responsibility in Scotland. In Principles and Practice of Forensic Psychiatry (eds R. Bluglass \& P. Bowden). Edinburgh: Churchill Livingstone.

Emmins, C. (1986) Unfitness to plead: thoughts prompted by Glenn Pearson's case. Criminal Law Review, 604-618.

Home Office and Department of Health and Social SECURITY (1975) Report of the Committee on Mentally Abnormal Offenders. Cmnd 6244. London: HMSO.

Normand, A. C. (1984) Unfitness for trial in Scotland: proposed adjudication of the facts and the right to reprosecute. International Journal of Law and Psychiatry, $7,415-435$.

Scottish Home and Health Department and Crown OfFICE (1975) Criminal Procedure in Scotland (second report). Cmnd 6218. Edinburgh: HMSO.

\title{
Trends in recruitment of new long-stay male schizophrenics
}

\author{
Norman A. Todd, Consultant Psychiatrist; ERnest H. Bennie, Consultant Psychiatrist; \\ A. F. COOPer, Consultant Psychiatrist; JosePh P. MCKane, Consultant Psychiatrist; \\ and Linda J. WATt, Consultant Psychiatrist, Leverndale Hospital, Glasgow G53 7TU
}

In 1973 a survey was carried out of male schizophrenic patients who had become long-stay residents in Leverndale Hospital, Glasgow, 'long-stay' being defined as having been continuously in hospital for more than three years (Todd et al, 1976). The patients were recruited from a four year cohort of admissions in the years 1967 to 1970 inclusive. In the following years there have been many changes in the provision of facilities and in clinical practice. In some countries, such as Italy, the USA and England, there has been a strong drive to reduce long-stay populations along with the closure of some mental hospitals. In Scotland the process has been much more gradual, possibly reflecting the differences in preexisting provisions and patterns of care.

Since 1973 there have, nevertheless, been major developments in Glasgow. The community nursing service, group homes, day hospitals and out-patient clinics at health centres have all added to the network of community support, although hostel accommodation has not yet played a significant part. Pro- grammes of rehabilitation have been developed in the hospital and linked to the other facilities. The main treatment advance during these years has been the increasing use of depot neuroleptic therapy. In view of these changes, a further survey was carried out in 1987.

Male patients were identified on 12 April 1987 from an annual hospital census as having been admitted with a diagnosis of schizophrenia (ICD-9) for the four years April 1980 to April 1984, and not discharged. They were assessed in respect of age, duration of illness, number of previous admissions, marital status, place of origin, occupation in hospital, and any special characteristics.

It has to be explained that during the period between 1973 and 1987 there were changes in the catchment area of Leverndale Hospital which is now shared with a neighbouring district general hospital psychiatric unit. This unit, however, has always been able to refer patients to Leverndale Hospital if longterm care is required. The inner-city population has 